\title{
Biotechnology and God
}

The biotechnology industry, which for years has had to fight subtle and not-so-subtle public fears that its scientists might loose dangerous laboratory-made organisms on innocent citizens, now faces an even greater challenge. In the name of God, a coalition of religious groups that include Christians, Jews, Muslims, and Hindus has thrown down the gauntlet against patenting 'life forms' such as human genes and human cell lines.

Richard D. Land of the Southern Baptist Convention puts the opposition's position well: "I think we're on the threshold of mind-bending debates about the nature of human life and animal life. We see altering life forms and creating new life forms as a revolt against the sovereignty of God and an attempt to be God."

This new movement, which is taking root in the United States but will, no doubt, attract a sincere following in other nations, is the handiwork of Washington activist Jeremy Rifkin. Rifkin, who founded something called the Foundation on Economic Trends, has been unrelenting in his opposition to biotechnology in all its manifestations, and it is easy to dismiss him as an antiscience fringe character. Convincing people to oppose biotechnology in the name of God is no small feat.

The movement to stop the patenting of living organisms, whether through Congress, the courts, or the court of public opinion, is barely weeks old, yet representatives of the biotechnology industry are already taking a defensive and, quite possibly, self-defeating tack. The essential argument is an economic one that goes this way: (1) patents are the life-blood of the new biotechnology industry (just as they are for drug companies); (2) without the right to protect research discoveries with patents, biotechnology companies could not attract the millions of dollars in capital investment they need to develop a product; and (3) without new biotechnology products, patients with life-threatening or debilitating diseases will be denied the gift of a cure.

In principle, the biotechnology industry is correct. The translation of scientific discovery to useful biotechnology products for medicine or agriculture requires the right to patent. But arguing that profits are more important than the laws of God is none too bright. Arguments about life-saving drugs may also fail to persuade. It was biotechnology, after all, that gave us the clot-buster tPA for heart attack victims, at thousands of dollars per treatment. But an existing agent, streptokinase, costs much less and often works as well. Similarly, human growth hormone, at $\$ 20,000$ a year, is invaluable for children destined to be abnormally short, but there is legitimate debate about its use as a drug to turn normal youngsters into basketball players. The simple message here is that the argument about life-saving drugs isn't winning-yet.

One could claim, sensibly, that the whole notion that there is something ungodly in patenting 'life forms' reflects an uneducated view of what genes and biotechnology are all about. A good biochemist would rightly say that genes are but bits of DNA-mere chemicals, nothing more. Indeed, a strong case could be made for dropping the term 'gene therapy' altogether, in favor of the more emotionally neutral idea of DNA therapy.

But it is too late for that now. There is a reason that people are concerned about what is happening in the scientific laboratories that isolate, transform, and patent human genes and cells. The research community itself has, in the interest of its own unappreciated good citizenship, taught people that certain hazards lurk in the world of biotechnology. The public has been carefully taught that certain experiments must be performed in high-containment facilities, lest potentially dangerous organisms are released into the atmosphere. Those who follow the science press know that not a single experiment in human gene therapy is permitted without the explicit permission of national ethical and safety review bodies. It is not a great leap of imagination to infer that there must be something especially dangerous or ethically novel to warrant such oversight.

For years, the ethics of research in biotechnology have been debated in limited public forums-the US National Institutes of Health holds open meetings to discuss new protocols, for instance. But it was inevitable that at some point these issues would find their way to broader public discourse. Religious leaders of all faiths promise to bring the godless patent to their congregations. Researchers should not dismiss this as the idle work of Luddites.

It may be necessary to reconsider the profit motive as the engine that now drives so much research in biotechnology. It is conceivable that agencies like the $\mathrm{NIH}$ could develop new patterns of research and development or that the assignment of royalties could be changed to reflect the central role of taxpayer-funded research in biotechnology. Maybe the system could change to protect the best in science while also acknowledging the legitimacy of responses to research that are more heartfelt than scientific. It is particularly urgent to deal responsibly with this movement because, in the end, we really do need biotechnology to improve human health and life.

Barbara J. Culliton 